WHC-EP-0804

Revision 0

UC-2020

\title{
Corrosion Assessment of Dry Fuel Storage Containers
}

C. E. Graves

Date Published

September 1994

Prepared for the U.S. Department of Energy Office of Environmental Restoration and

Waste Management

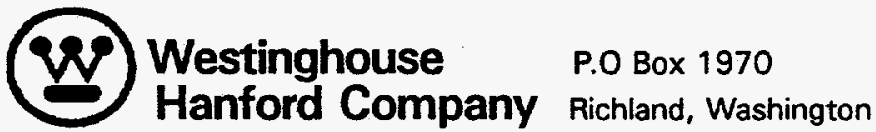

Hanford Operations and Engineering Contractor for the

U.S. Department of Energy under Contract DE-AC06-87RL10930

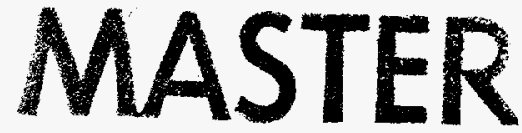

Approved for Public Release 


\section{DISCLAIMER}

This report was prepared as an account of work sponsored by an agency of the United States Government. Neither the United States Government nor any agency thereof, nor any of their employees, make any warranty, express or implied, or assumes any legal liability or responsibility for the accuracy, completeness, or usefulness of any information, apparatus, product, or process disclosed, or represents that its use would not infringe privately owned rights. Reference herein to any specific commercial product, process, or service by trade name, trademark, manufacturer, or otherwise does not necessarily constitute or imply its endorsement, recommendation, or favoring by the United States Government or any agency thereof. The views and opinions of authors expressed herein do not necessarily state or reflect those of the United States Government or any agency thereof. 


\section{DISCLAIMER}

Portions of this document may be illegible in electronic image products. Images are produced from the best available original document. 


\section{RELEASE AUTHORIZATION}

\begin{tabular}{ll} 
Document Number: & WHC-EP-0804, Rev. 0 \\
\hline Document Title: & Corrosion Assessment of Dry FueT Storage Containers \\
\hline Release Date: & $9 / 20 / 94$
\end{tabular}

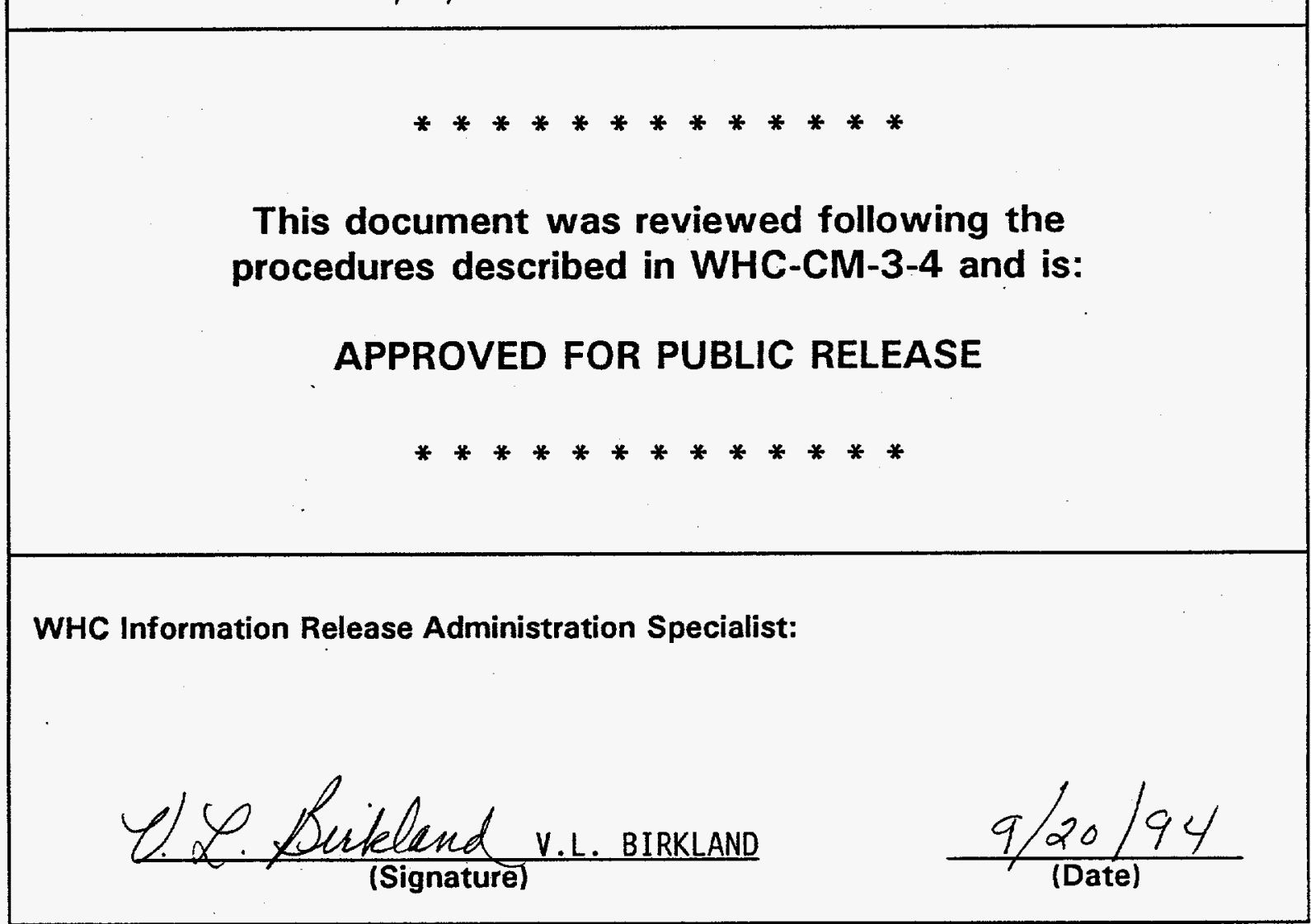


WHC-EP-0804

Rev. 0

\section{CORROSION ASSESSMENT OF DRY FUEL STORAGE CONTAINERS}

\section{Executive Summary}

The structural stability as a function of expected corrosion degradation of 75 dry fuel storage containers located in the 200 Area Low-Level Waste Burial Grounds was evaluated. These containers include 22 concrete burial containers, 13 55-gal (208-l) drums, and 40 Experimental Breeder Reactor II (EBR-II) transport/storage casks. All containers are buried beneath at least 48 in. of soil and a heavy plastic tarp with the exception of 35 of the EBR-II casks which are exposed to atmosphere. A literature review revealed that little general corrosion is expected and pitting corrosion of the carbon steel used as the exterior shell for all containers (with the exception of the concrete containers) will occur at a maximum rate of $3.5 \mathrm{mil} / \mathrm{yr}$. Penetration from pitting of the exterior shell of the 208-l drums and EBR-II casks is calculated to occur after 18 and 71 years of burial, respectively. The internal construction beneath the shell would be expected to preclude containment breach, however, for the drums and casks. The estimates for structural failure of the external shells, large-scale shell deterioration due to corrosion, are considerably longer, 39 and 150 years respectively for the drums and casks. The concrete burial containers are expected to withstand a service life of 50 years. 
WHC-EP-0804

Rev. 0

CORROSION ASSESSMENT OF DRY FUEL STORAGE CONTAINERS

Prepared by:
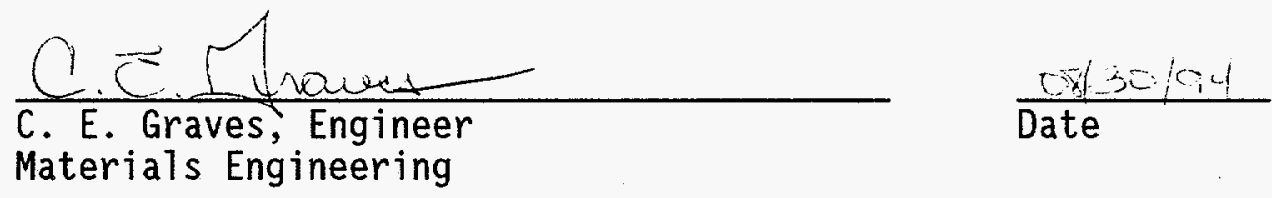

Materials Engineering

Reviewed by: Mrlemean

D. R. Duncan, Engineer

Solid Waste Systems Engineering

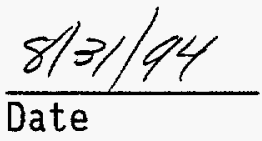

Approved by:

W7 Brehn

W. F. Brehm, Manager

Materials Engineering

$\frac{\delta-3 !-94}{\text { Date }}$
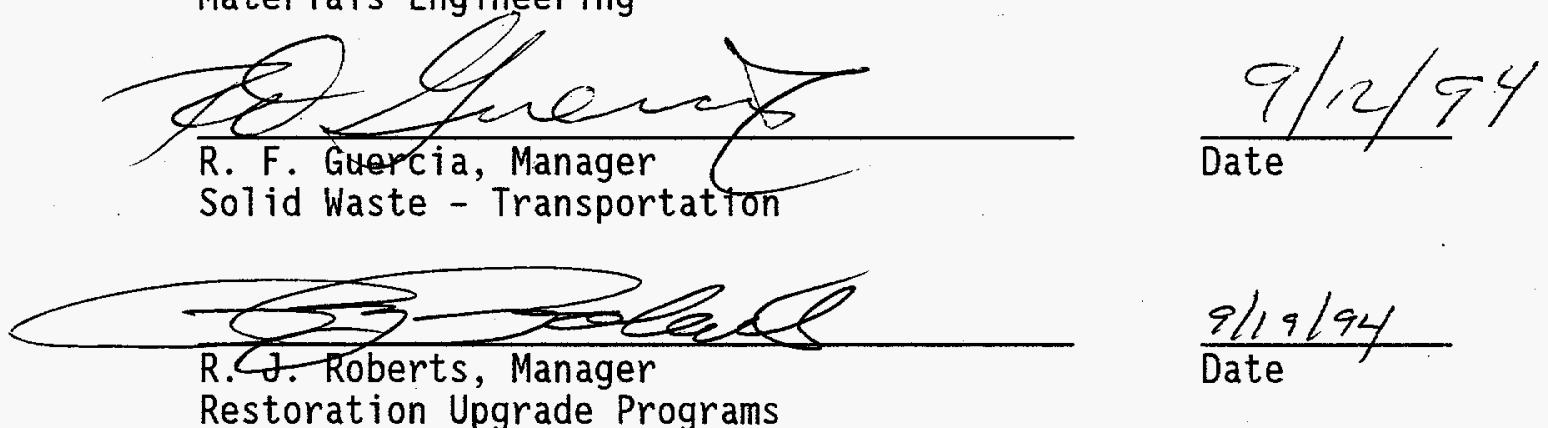

$\frac{9119 / 94}{\text { Date }}$ 
WHC-EP-0804

Rev. 0

CORROSION ASSESSMENT OF DRY FUEL STORAGE CONTAINERS

CONTENTS

$\underline{\text { Page }}$

1.0 INTRODUCTION . . . . . . . . . . . . . . . . . . . . 1

2.0 CONTAINER DESCRIPTION . . . . . . . . . . . . . . . . . . . 1

2.1 Concrete Burial Containers . . . . . . . . . . . . . . . . 1

2.2 55-Gallon (208-l) Drums ................. 2

2.3 EBR-II Transport/Storage Casks . . . . . . . . . . . 2

3.0 CONTAINER ENVIRONMENTS AND EXPECTED CORROSION MECHANISMS . . . . . 6

3.1 Atmospheric Corrosion . . . . . . . . . . . . . . . 6

3.2 Soil and Plastic Tarp................. 7

4.0 CONTAINER LIFE ESTIMATES . . . . . . . . . . . . . . . . . . . 9

4.1 Concrete Burial Containers . . . . . . . . . . . . 9

4.2 55-Gallon (208-l) Drums ............... . . 9

4.3 EBR-II Transport/Storage Casks . . . . . . . . . . . 10

5.0 CONCLUSIONS . . . . . . . . . . . . . . . . . . . . . 11

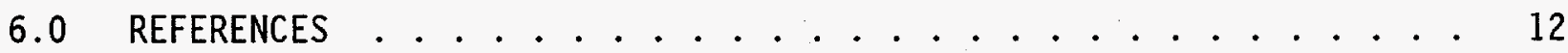

\section{LIST OF FIGURES}

Page

2.1. Concrete Burial Containers for Long Waste Liners . . . . . . . . . 3

2.2. 208- $\ell$ Drums for TRIGA Fuel Element Wastes . . . . . . . . . . . . 4

2.3. EBR-II Transport/Storage Cask ................ . 5

\section{LIST OF TABLES}

Page

4.1. 208- $\ell$ Drum Corrosion Loss . . . . . . . . . . . . . . . 9

4.2. EBR-II Cask Corrosion Loss . . . . . . . . . . . . . . . . 10 
Rev. 0

\section{CORROSION ASSESSMENT OF DRY FUEL STORAGE CONTAINERS}

\subsection{INTRODUCTION}

Beginning in 1970 transuranic (TRU) wastes were to be packaged and stored in such a manner that the waste packages could be easily retrieved, after a period of up to twenty years, in an intact contamination-free condition. In 1972, the Atlantic Richfield Hanford Company (the Hanford site contractor responsible for the operations at that time) started placing TRU wastes packaged in 55-gal drums in a concrete-lined "V" shaped trench. In 1973, because of excessive costs, the trench design was changed to specially constructed gravel and asphalt pads in flat-bottomed trenches.

This report addresses 75 containers of fuel and fue 7 pieces retrievably stored in the 200 Area Low-Level Waste Burial Grounds. These storage containers are of three different designs:

- Concrete burial containers with steel waste 1 iners

- 55-gal (208- $\ell$ ) drums for Training Research and Isotope Production, General Atomics.(TRIGA) Fuel Element Storage

- Experimental Breeder Reactor II (EBR-II) Transport/Storage Casks.

Approximately half of these containers are uncovered at the end of a burial trench while the remainder are covered by a layer of heavy plastic covers and several feet of earth.

of particular interest is the current condition of the burial container exteriors. This report assesses their state of corrosion degradation expected now and in the future. The containers and their environment are described, in addition to the expected corrosion mechanisms and rates. The times for container penetration or loss of structural integrity are estimated.

\subsection{CONTAINER DESCRIPTION}

\subsection{CONCRETE BURIAL CONTAINERS}

Figure 2.1 shows a schematic of the concrete burial containers for the long waste liner containers (reference drawing $\mathrm{H}-2-37434$ [H-2-3751] for the similar short waste liners]). Each storage container provides four separate steel vessels, each of which can hold one aluminum waste liner. The steel vessel sides are composed of schedule 40 piping (American Society for Testing and Materials [ASTM] A-53 carbon stee ${ }^{1}$ ) while the bottom plate is 0.25 -in.-thick ASTM A-36 carbon steel ${ }^{2}$. The four steel vessels are separated by at least $8 \mathrm{in}$. of concrete, with $20 \mathrm{in}$. of concrete on both the sides and

1 ASTM A-53 composition: $0.3 w t \%$ C, $1.2 w t \%$ Mn, $0.05 w t \% P, \& 0.06 w t \%$ Si.

2 ASTM A-36 composition: $0.29 w t \%$ C, 0.8 to $1.2 w t \%$ Mn, $0.04 w t \%$ P, $0.05 w \mathrm{t} \% \mathrm{~S}, 0.15$ to $0.3 \mathrm{wt} \% \mathrm{Si}, \& 0.2 \mathrm{wt} \% \mathrm{Cu}$. 
Rev. 0

bottom. According to drawing specifications, the concrete was to develop a $4,0001 \mathrm{bf} / \mathrm{in}^{2}$ compressive strength at 28 days in accordance with HPS-512-AC (Hanford Plant Standard) and HWS-4799 (GE 1962). The lifting bails on the concrete containers are 1.0-in.-thick ASTM A-36 plate, while the bails on the steel liners are 0.25 -in.-diameter ASTM A-36 rod.

There are 22 of these containers located at burial ground $218-W-3 A$, trench T08, where they are covered with several feet of earth. It is not known whether a heavy plastic tarp was used as a barrier: The containers were buried between April and June 1974.

\subsection{5-GALLON (210- $\ell)$ DRUMS}

Figure 2.2 shows a schematic of the 55-gal (208- $\ell$ ) drums used for TRIGA fuel element storage (reference drawing H-4-101690). These drums conform to U.S. Department of Transportation (DOT) specifications 17-C galvanized carbon steel drums with a total nominal thickness of 0.064 in. (64 mil) including the zinc coating on both sides of the steel (0.0021 in. [2.1 mil] each). An inner lead-shielded containment liner provides fuel storage. This carbon steel (ASTM A-36 and A-53) inner Tiner is separated from the drum sides by a concrete filling. The lifting bails are 0.5 -in.-diameter steel eye nuts attached to ASTM A-500 structural tubing (welded to drum).

There are $1355-$ gal $(208-\ell)$ drums located in burial ground $218-W-4 C$, trench 07 where they are covered by a plastic tarp under several feet of earth. The drums were buried in March 1987.

\subsection{EBR-II TRANSPORT/STORAGE CASKS}

Figure 2.3 shows a schematic of an EBR-II transport/storage cask (reference drawing H-2-68598). The cask exterior, constructed of ASTM A-36 carbon steel, uses 5 in. of poured lead for shielding. The cask sides are $0.375-i n$. thick, the bottom is $0.25-i n$. thick, while the cask's top ring is 1.25-in. thick. The overall cask dimensions are 17.5-in. in diameter and 59.5-in. in 7ength. A 6-in.-diameter by 42-in.-long cavity is provided for the inner containment of the irradiated fuel waste. All exposed exterior surfaces were painted with one coat of primer (Amercoat \#86) and two coats of finish (Amercoat \#33) with a nominal total thickness of $0.003-$ in. ( $3 \mathrm{mils}$ ). The lifting lug is a 1.5-in.-diameter ASTM A-36 carbon steel bar supported by a 0.375-in.-thick steel assembly (also A-36) welded to the cask exterior.

There are 35 EBR-II casks located in burial ground 218-W-4C, trench 01 , where they are exposed to the open air. Length of cask exposure varies as a result of different burial times: April - May 1981; September 1982; February 1983; December 1984; Apri1 - June 1989; and Apri1 - May 1990. Five additional casks are 1ocated in burial ground $218 \mathrm{~W}-3 \mathrm{~A}$, trench TS-6, where they are covered by a heavy plastic tarp and several feet of earth. These casks were buried during March and Apri1 1987. 
WHC-EP-0804

Rev. $O$

Figure 2.1. Concrete Burial Containers for Long Waste Liners.
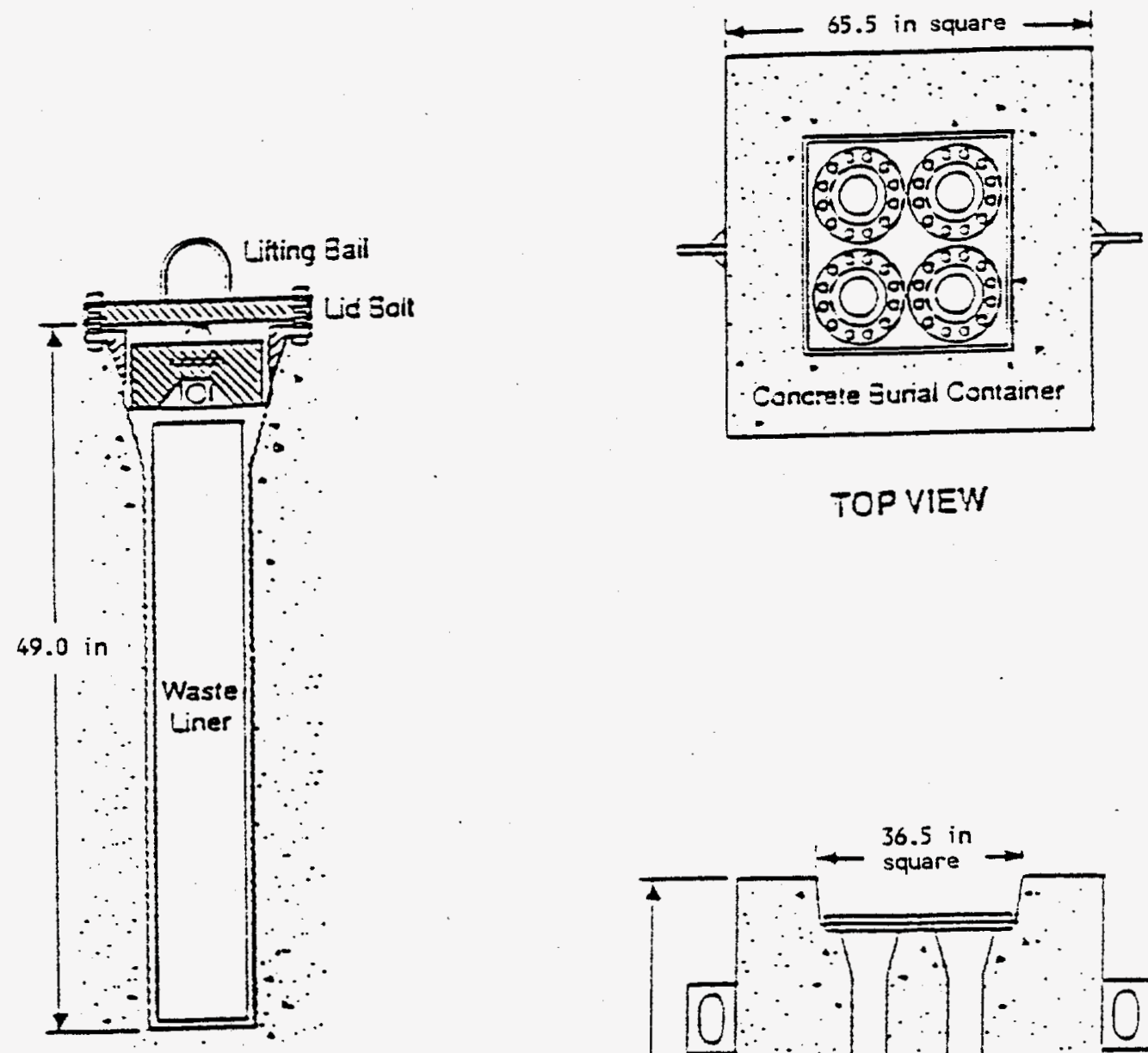

LNNER CONTAINEA

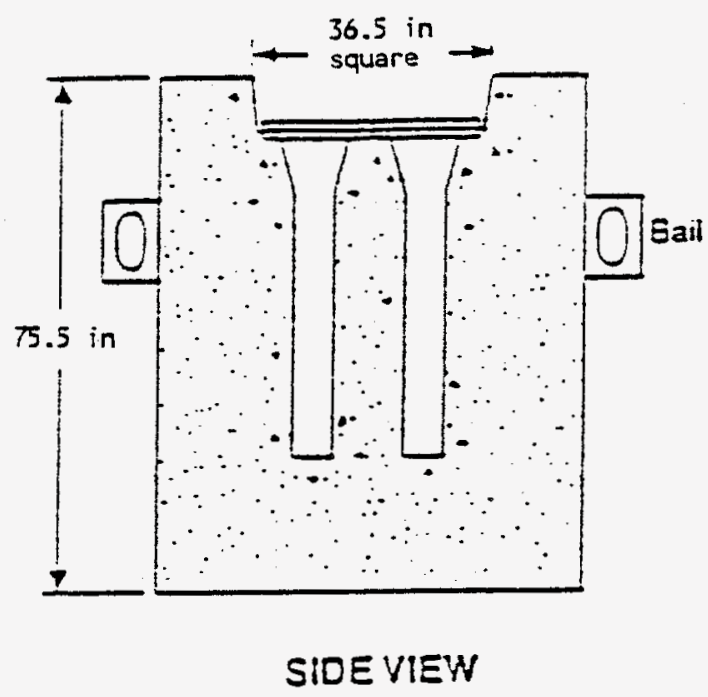




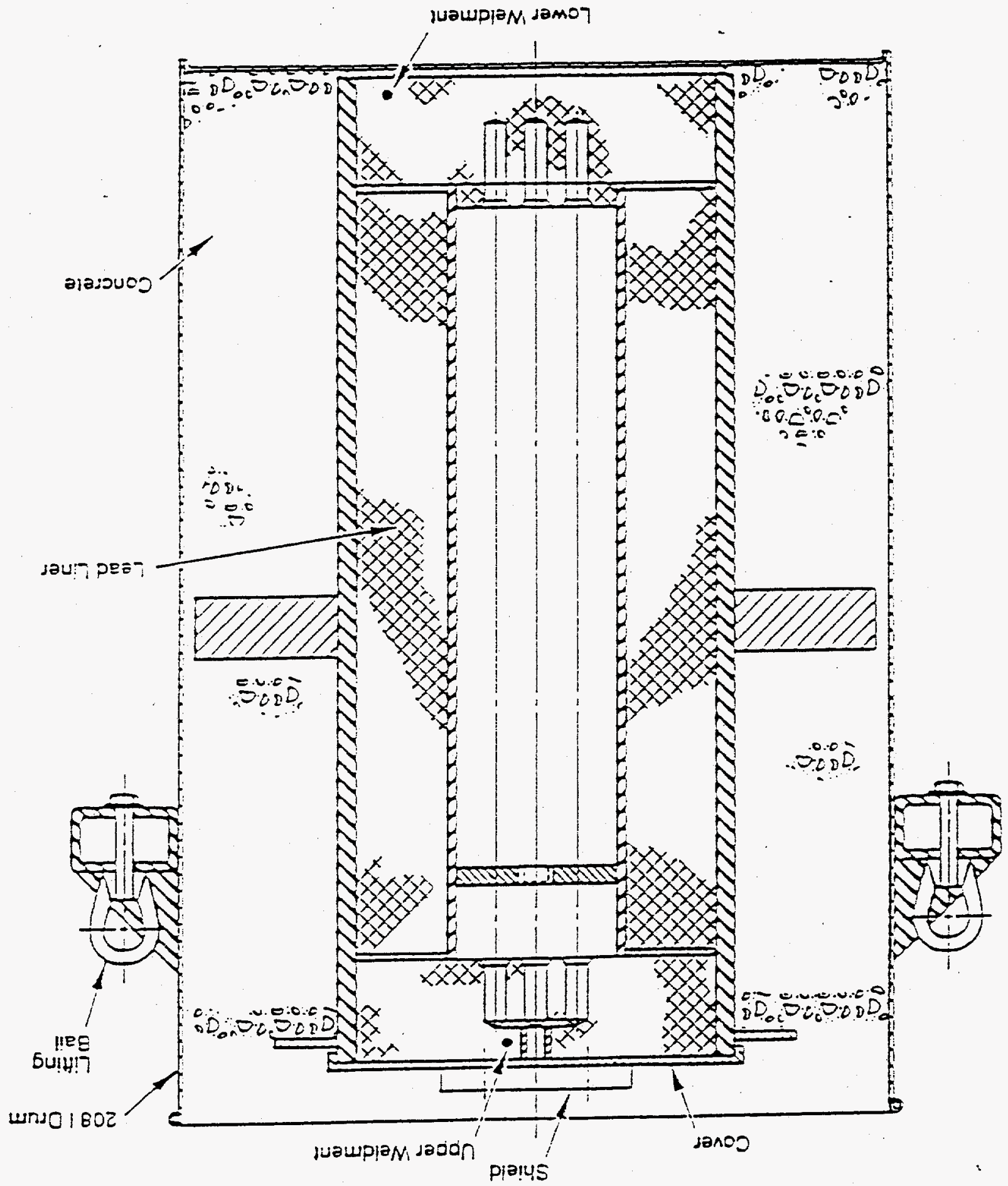

- safsem quawa 13 Lan」 $\forall 9 I y \perp$ log sundo $\gamma-802$ ' $2 \cdot 2$ aגn6! 
WHC-EP-0804

Rev. 0

Figure 2.3. Experimental Breeder Reactor II Transport/Storage Cask.
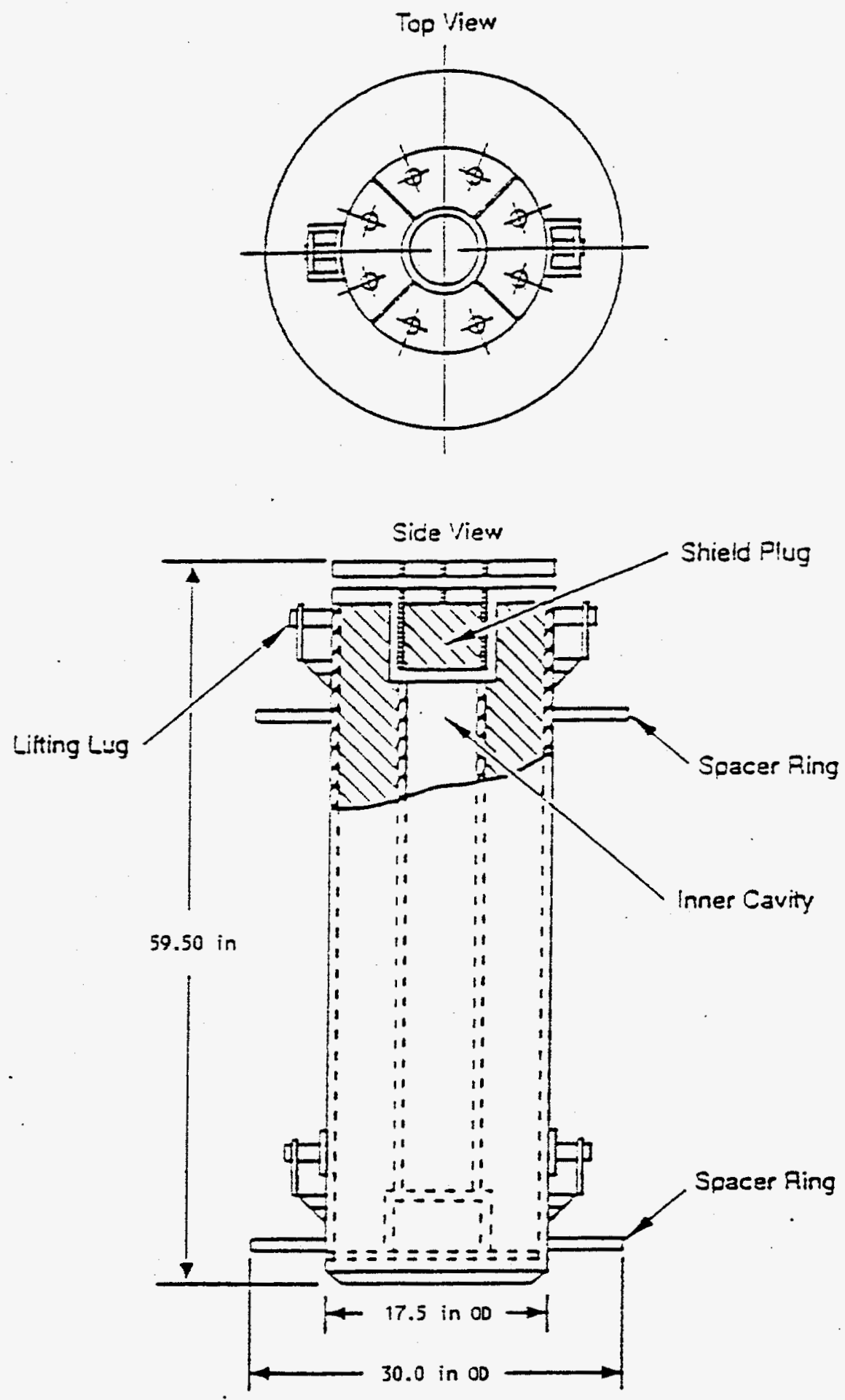
Rev. 0

\subsection{CONTAINER ENVIRONMENTS AND EXPECTED CORROSION MECHANISMS}

For the 75 burial containers, only two environments need be considered: atmosphere and soil (with a heavy plastic tarp between the soil and the containers).

\subsection{ATMOSPHERIC CORROSION}

Atmospheres vary considerably with respect to moisture, temperature, and contaminants; hence atmospheric corrosion rates also vary. On the basis of recognized differences, atmospheres have been divided into six types: marine, industrial, tropical, arctic, urban, and rural (Uhlig et al. 1985). Specific factors influence the corrosivity of atmospheres:

- Dust content - On a weight basis, dust is the primary contaminant of many atmospheres. Industrial atmospheres may carry suspended particles of carbon and carbon compounds, metal oxides, $\mathrm{H}_{2} \mathrm{SO}_{4},\left(\mathrm{NH}_{4}\right)_{2} \mathrm{SO}_{4}, \mathrm{NaCl}$, and other salts (Uhlig et al. 1985). Marine atmospheres contain salt particles that, when combined with moisture, initiate corrosion by forming galvanic cells or electrolytes on the metal surface.

- Gases in the atmosphere - Sulfur dioxide, a by-product from the burning of coal, oil, and gasoline, is the most corrosive constituent of industrial atmospheres. In the presence of moisture, $\mathrm{SO}_{2}$ forms sulfurous and sulfuric acids, both of which are very corrosive. Industrial atmospheres can be 50 to 100 times more corrosive than desert areas (Fontana 1986).

- : Moisture content - A critical relative humidity exists below which corrosion is negligible. In general, experimental values are found to fall between 50 and $70 \%$ for steel, copper, nickel, and zinc (Uhlig et al. 1985). Susceptibility to atmospheric corrosion depends on the percentage of time that the critical humidity is exceeded, in addition to dust and corrosive gas content.

The Hanford Site falls into the rural category because of its dry, desert atmosphere with a relative absence of industrial pollutants.

The predominant corrosion mechanism for the Hanford environment is uniform or general corrosion. Condensate or rainwater buildup on the container lids could cause localized pitting corrosion (a localized attack that results in cavities or pits in the metal). The buildup of water on the asphalt pad is prevented by a small trough between the pad and the trench wall that allows rainwater to drain away from the containers while the trench is open.

Corrosion rates for a carbon steel in an arid rural environment (Phoenix, Arizona) were reported to be $0.18 \mathrm{mil} / \mathrm{yr}$ (ASM 1978). It has also been observed that the corrosion rate for steel decreases with time because of the formation of an adherent rust film that protects the steel beneath it. 
Rev. 0

Pacific Northwest Laboratories (PNL) is conducting Task $E$, the container corrosion study portion of the Solid Waste Technology Support Program (SWTSP) for Westinghouse Hanford Company (Bunnell et al. 1994). The main objective is to provide defensible real-time data on the corrosion of low-carbon steel in the environment of the burial containers mentioned here. Two complete sets of test specimens are scheduled to be retrieved during fiscal year (FY) 1994, one at six months exposure and another after one year.

\subsection{SOIL AND PLASTIC TARP}

\subsubsection{Carbon Stee]}

A study by Carlos (1992) identified several specific factors that influence the corrosivity of soil:

- Moisture content - Annual precipitation and soil physical properties (i.e., texture) control soil moisture content. Annual precipitation at Hanford is low at $6.3 \mathrm{in} / \mathrm{yr}$ (Stone et al. 1983) and moisture content in the soil is between 5\% and 10\% (Ta17man et a1. 1979). This moisture content is considered low and thus yields low corrosion rates.

- Texture - Corrosivity of a soil can be affected by soil texture. Stones of different sizes in contact with an object can resuit in oxygen and moisture changes and create a galvanic cell (localized attack). Hanford soil texture is described as relatively coarse-grain, silty-sandy gravel with about $21 \%$ cobbles and pebbles (Tallman et al. 1979).

- Porosity - Soil porosity is a measure of the void space in the soil by volume percent. Hanford soil is highly aerated (i.e., has large air pore space) (Ta17man et a1. 1979) indicative of a dry soil.

- Resistivity - Soil corrosiveness is inversely related to soil resistivity. Measurements on Hanford soil (Carlos 1992) in various locations yielded readings between 8500 and $50,000 \mathrm{ohm}-\mathrm{cm}$, corresponding to a mildly or very mildly corrosive soil, respectively (Romanoff 1957).

- Chemical composition and $\mathrm{pH}$ - Chlorides or sulfides present in high concentrations have been shown to be corrosive. Hanford soil does not contain significant levels of sulfides or chlorides and is not expected to promote corrosion under normal conditions.

The potential corrosivity of a soil is related to soil acidity or alkalinity. The values for $\mathrm{pH}$ range from 0 to 6 for acidic soils and 8 to 14 for alkaline soils ( 7 being neutral). For selected Hanford sites, Carlos (1992) measured an average soil $\mathrm{pH}$ of 8 , which is considered close to being a nonaggressive soil.

- Temperature - Corrosion rates normally increase with increasing temperature.

- Burial duration - Romanoff (1957) showed that corrosion rates for buried objects decreased with time. 


\section{WHC-EP-0804}

Rev. 0

The burial containers are covered on both the top and sides with a heavy plastic tarp, then backfilled with a minimum of 48 in. of earth. The tarp is similar to materials (hypaton) used for swimming pool liners and has a thickness of $12 \mathrm{mils}$. The plastic cover reduces the possibility of localized attack by two methods:

- Prevents container coating damage during backfili operations. Breaches of the container coating would result in a small anode-large cathode area relationship that promotes pitting corrosion.

- Prevents direct container-soil contact, thereby reducing the probability of galvanic corrosion resulting from stones in the soil.

Conversely, the tarp cover increases humidity within the storage module because of water vapor diffusion from the soil. Previous studies have indicated that humidities of 90 to $95 \%$ exist within the storage module under these conditions.

Different corrosion rates for carbon steels in Hanford soil have been reported. Divine (1991) states that long-term corrosion rates for low-carbon steel in Hanford soil average between 3 and $6 \mathrm{mil} / \mathrm{yr}$. Task $E$ Container Corrosion Studies (Bunnell et al. 1994) measured a Hanford soil uniform corrosion rate of approximately $1 \mathrm{mil} / \mathrm{yr}$ using resistance probes buried about 48 in. (near the trench floor) in trench 24 of the 218-W-4C Burial Ground. A study of 30 underground carbon steel fuel storage tanks (Carios 1992) estimated a maximum pitting corrosion rate to be $3.5 \mathrm{mil} / \mathrm{yr}$ in areas where the coating had been removed.

In April 1982 an in situ inspection of stored burial containers (painted DOT Specification 17-H carbon steel drums) was conducted (Morton 1982). For drums in storage just over $8 \frac{1}{2}$ years, a maximum corrosion rate of 1 mil/yr was [ultrasonically] measured at the drum-plastic interface. A visual inspection indicated that there was no significant pitting corrosion. It was also noted that drum location within the storage module affected the corrosion rate. Exterior drums corrode faster than interior drums, lower tier drums corrode faster than upper tier drums, and accelerated corrosion occurs at all drumplastic interfaces (because of condensate on plastic).

In addition to the atmospheric corrosion values, the Task E Container Corrosion Study (Bunnell et. al 1994) will measure real-time corrosion on low-carbon steels in soil at different depths. Test samples will be removed after soil exposure times of $\frac{1}{2}, 1,2,4,8$, and 16 years. Retrieval of the six-month and one-year test specimens is scheduled to occur during FY 1994.

\subsubsection{Concrete}

The sulfates of sodium, potassium, and magnesium present in alkali soils and waters will cause the deterioration of many concrete structures through the chemical reaction of the sulfates with the hydrated 1 ime and hydrated calcium aluminate in the cement (Carlos 1994). Even though soils at the Hanford site are alkali, they are low in sulfates (Tallman et al. 1979). Sulfate attack from soil also requires the presence of groundwater. Groundwater levels at the trench site are well below the asphalt pad bases. 
Rev. 0

\subsection{CONTAINER LIFE ESTIMATES}

\subsection{CONCRETE STORAGE CONTAINERS}

A review of the effects of environment on concrete and its reinforcement steel based on visual inspections and available non-destructive examination (NDE) results showed that Hanford soil is not very detrimental to concrete and reinforcing steel during a 50-year service life (Carlos 1994). Having been buried since 1974, the concrete burial containers could be expected to remain buried an additional 30 years without a loss of structural integrity.

The steel vessels (encasing the aluminum waste liners) and the individual lifting bails are subject to both general and pitting corrosion (pitting is the predominant corrosion mechanism). Container construction exposes only the vessel 1id (0.94-in.-thick carbon steel) to the environment. Carlos (1992) measured the rate of pitting corrosion at $3.5 \mathrm{mil} / \mathrm{yr}$ for buried carbon steel. This pitting rate divided by 50 -year burial time would yield pits only 0.175 in. [175 mil] deep, less than $20 \%$ of the original thickness.

The lifting bails pose a different problem in that both sides of the material are exposed to the environment, effectively doubling the pitting corrosion rate. Doubling the Carlos pitting rate over the 50-year burial time would yield pits $0.35-$ in. [350 mil] deep. The container 1ifting bails are 1.0-in.-thick plate and therefore would maintain structural integrity with pits of this size. The lifting bail for the steel vessels is smaller in thickness (0.25-in.-diameter rod) and would exhibit pitting penetration after 36 years of burial. These penetrations could be detrimental to the structural integrity of the bails.

\subsection{5-GALLON (208- $\ell)$ DRUMS}

The corrosion rate reported by Morton (1982) for tarp-enclosed painted carbon steel drums is a conservative figure for use on the 208- $\ell$ drums (galvanized carbon steel). The zinc coating imparts a more durable corrosion protection than the epoxy paints of the study. Table 4.1 calculates the present corrosion loss of the drums, based on the Morton corrosion data.

Table 4.1. 55-Gal (208-l) Drum Corrosion Loss.

\begin{tabular}{|c|c|c|c|c|}
\hline Environment & $\begin{array}{c}\text { Burial } \\
\text { Date }\end{array}$ & $\begin{array}{c}\text { Burial } \\
\text { Time } \\
\text { (years) }\end{array}$ & $\begin{array}{c}\text { Corrosion } \\
\text { Rate } \\
\text { (mils/yr) }\end{array}$ & $\begin{array}{c}\text { Estimated } \\
\text { Corrosion } \\
\text { Loss 8/94 } \\
\text { (mi 1s) }\end{array}$ \\
\hline Soi1 \& Plastic Tarp & $3 / 87$ & 7.4 & 1.0 & 7.40 \\
\hline
\end{tabular}

* Initial drum thickness: 0.064 inch (64 mils) 
Rev. 0

On the basis of the pitting corrosion rate of $3.5 \mathrm{mil} / \mathrm{yr}$ as measured by Carlos (1992), judgement is that drum pitting penetration would not occur until the eighteenth year of burial. This short lifespan can be attributed to localized accumulation of water on the tops and bottoms of the drums. The burial container's internal construction (concrete filler between drum and inner waste liner) would prevent penetration of the drum from leading to a breach of containment. Loss of the drum wall may affect handling as the integrity of the lifting bails depend on an intact drum wall. The estimated structural life of the drum is calculated to be $\approx 39$ years on the basis of an assumed container structural failure (collapse of container) at a wall thickness of $\approx 25 \mathrm{mils}$ ( $\approx 33 \%$ of original).

The container lifting bails also are subject to both general and pitting corrosion (pitting is the predominant corrosion mechanism). Again the pitting corrosion rate is doubled to take into account exposure of both sides of the material. Applying the Carlos pitting rate to the $0.5-i n$-diameter eye nut yields bail penetration after approximately 71 years.

\subsection{EBR-II TRANSPORT/STORAGE CASKS}

The Morton (1982) uniform corrosion rate, $1.0 \mathrm{mil} / \mathrm{yr}$, is also applied to the EBR-II casks because of the similarity in construction materials. The atmospheric corrosion rate of $0.18 \mathrm{mil} / \mathrm{yr}$ is applied to the exposed casks. Table 4.2 calculates the present corrosion loss for both environments.

Table 4.2. Experimental Breeder Reactor II Cask Corrosion Loss.

\begin{tabular}{|l|c|r|r|r|}
\hline Environment & $\begin{array}{c}\text { Burial } \\
\text { Date }\end{array}$ & $\begin{array}{c}\text { Burial } \\
\text { Time } \\
\text { (years) }\end{array}$ & $\begin{array}{c}\text { Corrosion } \\
\text { Rate } \\
\text { (mils/yr) }\end{array}$ & $\begin{array}{c}\text { Estimated } \\
\text { Corrosion } \\
\text { Loss 8/94 } \\
\text { (mi 1s) }\end{array}$ \\
\hline Atmosphere & $4-5 / 81$ & 13.3 & 0.18 & 2.39 \\
\cline { 2 - 5 } & $9 / 82$ & 11.9 & 0.18 & 2.14 \\
\cline { 2 - 5 } & $2 / 83$ & 11.5 & 0.18 & 2.07 \\
\cline { 2 - 5 } & $12 / 84$ & 9.7 & 0.18 & 1.75 \\
\cline { 2 - 5 } & $4-6 / 89$ & 5.3 & 0.18 & 0.95 \\
\cline { 2 - 5 } & $4-5 / 90$ & 4.3 & 0.18 & 0.77 \\
\hline \multirow{2}{*}{ Soi1 \& Plastic Tarp } & $3-4 / 87$ & 7.4 & 1.0 & 7.40 \\
\hline
\end{tabular}

* Initial cask thickness (bottom): 0.25 inch

The pitting corrosion rate as measured by Carlos (1992), $3.5 \mathrm{mil} / \mathrm{yr}$, would not lead to cask pitting penetration (through the bottom plate) until after 71 years of burial. The estimated structural life of the casks is calculated to be greater than 150 years on the basis of an assumed container 
Rev. 0

structural failure (collapse of container) at a wall thickness $33 \%$ of original thickness. The thickness value of the cask bottom was used for the calculations because of its smaller thickness and its probability of greater water contact on the asphalt pad.

The container lifting bails also are subject to both general and pitting corrosion (pitting is the predominant corrosion mechanism). Again the pitting corrosion rate is doubled to take into account the exposure of both sides of the material. Applying the Carlos pitting rate to the 1.5-in.-diameter lifting lug yields penetration after approximately 214 years.

\subsection{CONCLUSIONS}

Literature reveals that little general corrosion is expected and that pitting corrosion of the carbon steel will occur at a maximum rate of $3.5 \mathrm{mil} / \mathrm{yr}$. Penetration from pitting of the 55-gal $(208-\ell)$ drums is calculated to occur after 18 years of burial. For the buried EBR-II casks, penetration would not occur until after 71 years of burial. The estimates for loss of structural integrity are considerably longer, 39 and 150 years, respectively. The concrete burial containers are expected to withstand 50 years of burial without a loss of structural integrity. 
WHC-EP-0804

Rev. 0

\subsection{REFERENCES}

ASM, 1978, Metals Handbook, Ninth Edition, Volume 1, "Properties and Selection: Irons and Steel," American Society for Metals, Metals Park, Ohio.

Bunne11, L. R., L. A. Doremus, J. B. Topping, and D. R. Duncan, 1994, Task E Container Corrosion Studies: Annual Report, Westinghouse Hanford Company, Richland, Washington.

Carlos, W. C., 1992, Underground Fuel Storage Tank Corrosion Study, WHC-EP-0507, Rev. 1, Westinghouse Hanford Company, Rich]and, Washington.

Carlos, W. C., 1994, Hanford Reinforced Concrete Aging Assessment, WHC-SD-W236A-ES-009, In Preparation, Westinghouse Hanford Company, Richland, Washington.

Divine, J. R., 1991, A Review of the Hanford Site Soil Applicable to Solid Waste Containers, WHC-EP-0408, Westinghouse Hanford Company, Richland, Washington.

DOE-RL, Specifications for Placing Reinforced Concrete, HPS-512-AC, Rev. 2, U.S. Department of Energy, Richland Field Office, Richland, Washington.

Fontana, M. G., 1986, Corrosion Engineering, McGraw-Hi11, Inc., New York, New York.

GE, 1962, Standard Specification for Batching and Delivery of Concrete, HWS-4799, Rev. 4, General Electric Company, Richland, Washington.

Morton, R. L., 1982, Inspection of Retrievably Stored Transuranic Waste Containers, WHC-SD-WM-TRP-002, Rev. 0, Westinghouse Hanford Company, Richland, Washington.

Romanoff, M., 1957, Underground Corrosion Circular 579, National Bureau of Standards, Washington, D.C.

Stone, W. A., J. M. Thorp, 0. P. Gifford, and D. J. Hoitink, 1983, Climatological Summary for the Hanford Site, PNL-4622, Pacific Northwest Laboratory, Richland, Washington.

Ta11man, A. M., K. R. Fecht, M. C. Marratt, and G. V. 1ast, 1979, Geology of the Separation Area, Hanford Site, South-Central Washington, RHO-ST-23, Rockwell Hanford Operations, Richland, Washington.

Uhtig, H. H., and R. W. Revie, 1985, Corrosion and Corrosion Contro7, John Wiley \& Sons, Inc., New York, New York. 
WHC-EP-0804

Rev. 0

\section{DISTRIBUTION}

Number of copies

ONSITE

1

U.S. Department of Energy, Richland Operations Office

R. F. Guercia

$57-55$

1

Pacific Northwest Laboratory

Hanford Technical Library

P8-55

11

Westinghouse Hanford Company

W. F. Brehm

H5-67

W. C. Carlos

D. R. Duncan (2)

H5-67

C. E. Graves (2)

R. J. Roberts

H5-33

H5-67

Central Files

N3-13

Information Release Administration (3)

L8-04

H4-17

Distr-1 